\title{
Paternity Test Through Kinship Analysis as Forensic Identification Technique
}

\author{
Ahmad Yudianto, ${ }^{1,2,3}$ Fery Setiawan, ${ }^{2}$ Reni Sumino ${ }^{1}$ \\ ${ }^{1}$ Department of Forensic and Medicolegal Medicine Faculty of Medicine Universitas Airlangga/Dr. Soetomo \\ General Hospital Surabaya, Indonesia, ${ }^{2}$ Forensic Science Master Program, Postgraduate School of \\ Universitas Airlangga, Surabaya, Indonesia, ${ }^{3}$ Human Genetic Study Group, Institute of Tropical Diseases \\ Universitas Airlangga, Surabaya, Indonesia
}

\begin{abstract}
Paternity tests is often faced with the unavailability of information from the father, mother, or child as a comparison in forensic DNA examination process. Therefore, comparisons with information from close family lines are needed, for example from the victim's siblings or the perpetrator if there are no comparisons from parents or siblings. This study was conducted by the Human Genetic Study Group of Airlangga University in its campus from January to April 2020. The aim of the study was to analyze the use of kinship analysis in paternity test through STR CODIS examination on siblings. This was an observational laboratory study with a temporary design. DNA sample extraction level and purity results were measured with the mean DNA sample level of $675 \pm 5.35 \mathrm{ng} / \mu \mathrm{L}$, while the purity values ranged from 1.05 to 1.86. The paternity test principle is based on comparison process between the parents' alleles with the child's alleles. However, if the parents' alleles are not available, the siblings' alleles can be used as a comparison for identification purpose, which is known as kinship analysis. Statistically, full siblings have a 2 alleles accuracy probability of $(0.25) 25 \%$, which was the same as not having the same allele or 0 allele, while 1 allele accuracy reached 50\%. All CODIS STR loci had the highest percentage of 2 allele sharing. Therefore, it is recommended to use sibling or kinship analysis if both parents are absent.
\end{abstract}

Keywords: Kinship analysis, paternity test, sibling, STR CODIS

\section{Tes Keayahan Melalui Analisis Hubungan Kekerabatan Saudara sebagai Teknik Identifikasi Forensik}

\begin{abstract}
Abstrak
Tes paternitas seringkali dihadapkan tidak tersedianya informasi pihak ayah, ibu atau anak dijadikan sebagai pembanding dalam proses pemeriksaan DNA forensik. Oleh karena itu, diperlukan perbandingan dengan informasi dari garis keluarga dekat, misalnya dari saudara korban atau pelaku jika tidak ada pembanding dari orang tua atau saudara kandung. Penelitian dilakukan di Kelompok Studi Genetik Manusia Universitas Airlangga pada bulan Januari sampai April tahun 2020. Penelitian ini bertujuan menganalisis kinship dalam tes paternitas melalui pemeriksaan STR CODIS pada saudara kandung. Penelitian merupakan penelitian laboratorium observasional dengan desain sementara. Tingkat ekstraksi sampel DNA dan hasil kemurnian diukur, dengan tingkat sampel DNA rata-rata $675 \pm 5,35 \mathrm{ng} / \mu \mathrm{L}$, sedangkan nilai kemurnian berkisar 1,05-1,86. Prinsip uji garis ayah didasarkan pada proses perbandingan antara alel orang tua dengan alel anak. Namun jika alel orang tua tidak tersedia, maka alel saudara kandung dapat digunakan sebagai pembanding sebagai metode identifikasi yang disebut dengan analisis kinship. Secara statistik full sibling memiliki probabilitas akurasi 2 alel sebesar $(0,25) 25 \%$, nilai ini sama dengan tidak memiliki alel atau 0 alel yang sama, sedangkan akurasi 1 alel mencapai 50\%. Semua lokus CODIS STR memiliki persentase tertinggi dari 2 pembagian alel. Oleh karena itu, disarankan untuk menggunakan analisis saudara kandung atau kekerabatan jika kedua orang tua tidak ada.
\end{abstract}

Kata kunci: Analisis kinship, keluarga, STR CODIS, tes paternitas

Corresponding Author: Ahmad Yudianto, Department of Forensic and Medicolegal, Faculty of Medicine, Universias Airlangga, Surabaya, East Java, Indonesia . Jalan Prof. Dr. Moestopo No. 47, Surabaya 60132, Indonesia, Email: yudi4n6sby@yahoo.co.id 


\section{Introduction}

Individual forensic identification, especially a paternity test, is often faced with unavailability of information for deoxyribonucleic acid [DNA] comparison from the parents or children during the forensic examination process. Forensic DNA examination principle is based on allele comparison from the victim or the perpetrator that will be compared to the allele from the family or kinship lines (kinship analysis) in cases such as "unborn child dispute," paternity dispute, or even on forensic DNA analysis in mass disaster as well as war victims. In this condition, a comparison from close family lines is needed as one alternative in the forensic DNA analysis process. This comparison makes use of, among others, DNA from the siblings of the victims or the perpetrators when no comparison from the parents or children is possible. ${ }^{1}$

A paternity test is a tool to determine whether a man is the biological father of someone and is a legal procedure for fatherhood. It is challenging to determine paternity because there are a lot of things that need to be confirmed. Currently, determination of paternity starts with learning the similarity aspect or the absence of similarity between the child and the alleged father. The similarities analyzed include eye characteristics, hair color, distinct way of behaving or speaking, and height. ${ }^{2}$

The unavailability of information from both parents for comparison in identification examination process is one of the problems that might occur in forensic DNA analysis, especially in a paternity test. Therefore, a comparison from a close family or kinship line, such as from siblings, is needed as one alternative that might be considered in the forensic DNA analysis process. ${ }^{2,3}$

Kinship analysis in forensic DNA identification is used in various cases, for example: in parentage testing (both in civil and criminal cases), disaster victim identification, missing person identification, and search for a family member. Paternity testing through kinship analysis is not widely known in forensic identification examination. The objective of this study is to analyze kinship as a technique in forensic identification in paternity testing. ${ }^{4,5}$

\section{Methods}

This study used the population of all paternity test participants in the Human Genetic Institute Tropical Disease study group, Airlangga University, Indonesia. Samples were collected from the participants' peripheral blood of paternity testing that consisted of samples from a father, a mother, and two children. This study has obtained ethical eligibility from the Dentistry Faculty of Airlangga University under the ethical clearance No.: 275/HRECC.FODM/VI/2020. Twenty families participated in this study with a total of 80 samples. The whole process of the study was conducted at the human genetic study group of the Institute of Tropical Disease, Airlangga University, Indonesia.

Eighty peripheral blood samples were stored in tubes and labeled as A [father], B [mother], and $C$ [children] to refer the samples from the father, mother, and biological children. The DNA extraction process from 80 peripheral blood samples were performed using the DNAzol method (McClintock 2014) and the DNA pellets isolated were then added with $50 \mu \mathrm{L}$ of distilled water.

DNA amplification process was done through a Polymerase Chain Reaction (PCR) Machine (PowerPlex® 21Systems, Promega, USA) with certain DNA sequence region targets to make copies from the isolated DNA. All 80 samples were amplified using 13primer Short Tandem Repeats [STR] - Combined DNA Index System [CODIS] (TPOX, D3S1358, FGA, D5S818, CSFIPO, D7S820, D8S1179, THOI, vWA, D13S317, D16S539, D18S51, D21S11) and Amelogenin (Amel)x: 106bp, y: 112bp. The amplification setting for D3S1358,FGA,D8S1179,D18S51,D21S11 were as follows: $96^{\circ} \mathrm{C}-2$ minutes, followed by $\left[94^{\circ} \mathrm{C}-\right.$ 1 minute, $60^{\circ} \mathrm{C}-1$ minute, $70^{\circ} \mathrm{C}-1.5$ minutes, for 10 cycles], then $\left[90^{\circ} \mathrm{C}-1\right.$ minute, $64^{\circ} \mathrm{C}-1$ minute, $70^{\circ} \mathrm{C}-1.5$ minutes, for 25 cycles]. For CSF1PO, the setting was as follows: $96^{\circ} \mathrm{C}-2$ minutes, then $\left[94^{\circ} \mathrm{C}-1\right.$ minute, $64^{\circ} \mathrm{C}-1$ minute, $70^{\circ} \mathrm{C}-1.5$ minutes, for 10 cycles], followed by $\left[90^{\circ} \mathrm{C}-1\right.$ minute, $64^{\circ} \mathrm{C}-1$ minute, $70^{\circ} \mathrm{C}-1.5$ minute, for 30 cycles]. For D5S818, D7S820, D13S317, the setting was as follows: $96^{\circ} \mathrm{C}-1$ minute, followed by $\left[94^{\circ} \mathrm{C}-30\right.$ seconds, $60^{\circ} \mathrm{C}-30$ seconds, $70^{\circ} \mathrm{C}-45$ seconds, for 10 cycles], then $\left[90^{\circ} \mathrm{C}-30\right.$ seconds, $64^{\circ} \mathrm{C}-30$ seconds, $70^{\circ} \mathrm{C}-45$ seconds, for 30 cycles] and $60^{\circ} \mathrm{C}-30$ seconds. Meanwhile, for D16S539, the setting was as follows: $96^{\circ} \mathrm{C}-1$ minute, and then followed by $\left[94^{\circ} \mathrm{C}-1\right.$ minute, $59^{\circ} \mathrm{C}-1$ minute, $72^{\circ} \mathrm{C}-1.5$ minute, for 25 cycles] and $72^{\circ} \mathrm{C}-1$ minute. The DNA templates were stored at $4^{\circ} \mathrm{C}$ (Promega corp 2001). 


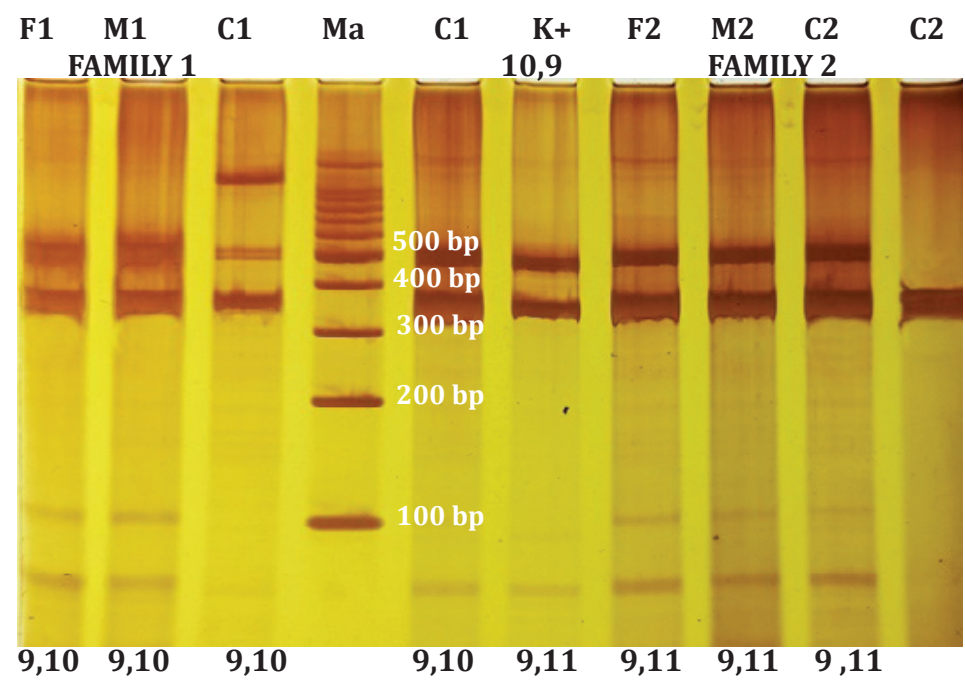

Figure 1 PCR CSF1PO locus [321bp-357bp] visualization, M [marker 100bp], A [father], B [mother], Ca [Child 1], Cb [Child 2]

\section{Results}

PCR results in visualization through vertical electrophoresis with $6 \%$ polyacrylamide agarose gel [PAGE] [Bio-Rad Mini-PROTEAN®] and Silver Nitrate staining are depicted below (Figure 1).

DNA band contrast visualization using locus CSF1PO establishment had responded within locus CSFIPO band limits formation (321bp-357bp) with an Ma of [100bp marker]. The sample of locus CSF1PO came from the DNA kinship paternity test from participants consisting of father, mother, and children. PCR amplification results' visualization were performed through Polyacrylamide Agorose Gel Electrophorese [PAGE].
PCR visualization reading from electrophoresis gel took the form of alleles in each locus with K562 control (Table 1). The STR Allele profile of 20 families consisting of the father (F), mother (M), and two children (C1 and C2) were described using 13 STR CODIS TPOX, D3S1358, FGA, D5S818, CSF1P0, D7S820, D8S1179, TH01, vWA, D13S317, D16S539, D18S51, D21S11, and Amelogenin loci.

The alleles were then matched between family members (father, mother, children) and the allele frequency values were determined (Table 2). The STR allele frequencies of 160 samples using 13 STR CODIS consisted of TPOX, D3S1358, FGA, D5S818, CSF1P0, D7S820, D8S1179, TH01, vWA, D13S317, D16S539, D18S51, D21S11, and

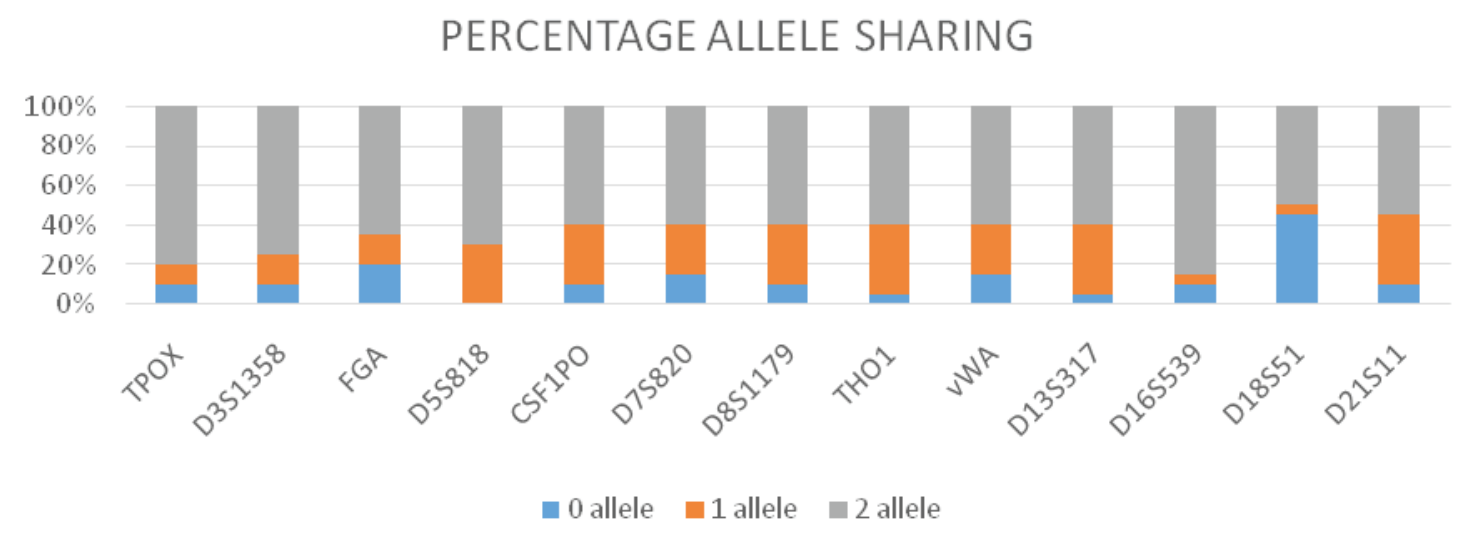

Figure 2 Allele Sharing Percentage on Siblings 
A Yudianto et al: Paternity Test Through Kinship Analysis as Forensic Identification Technique

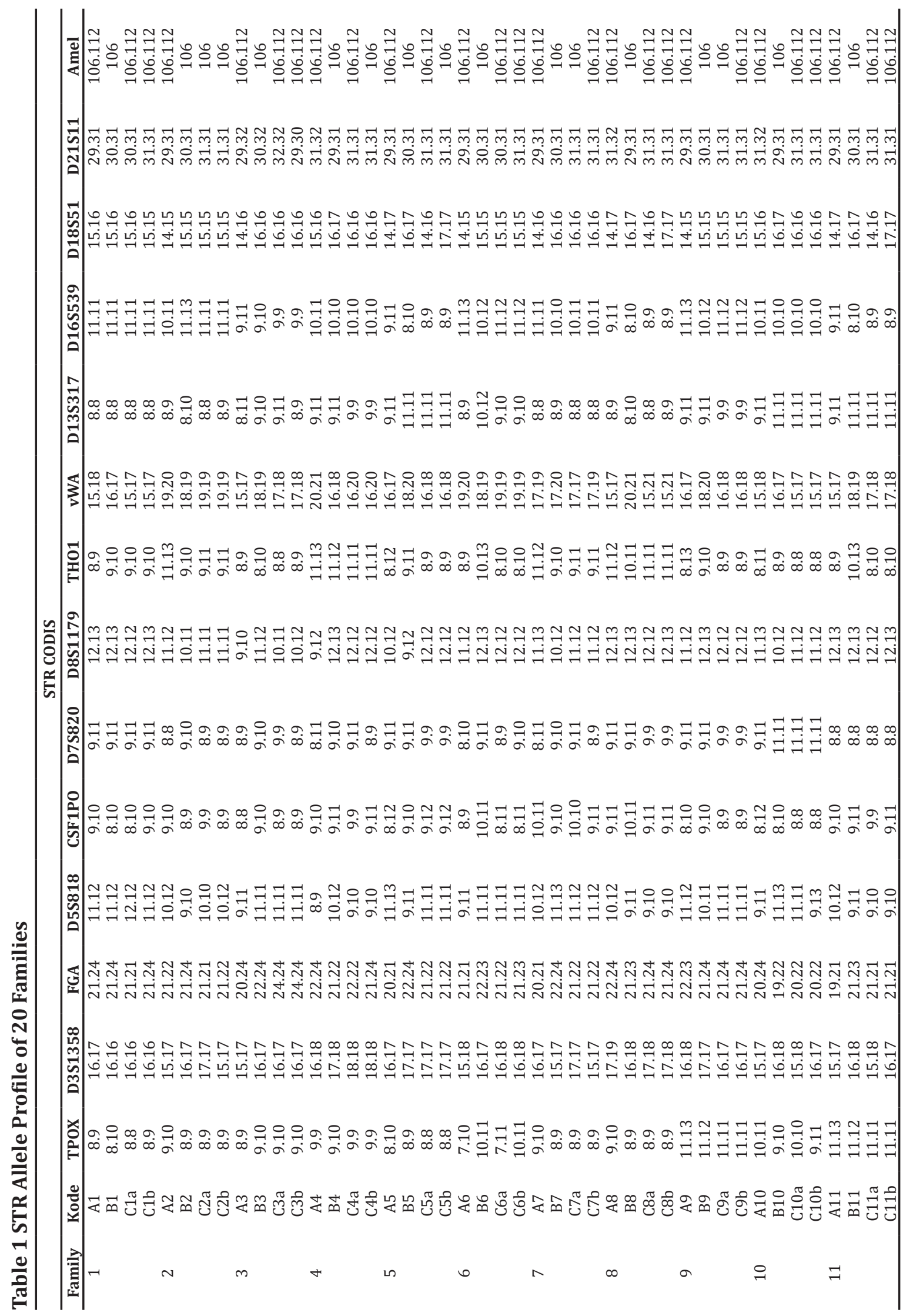




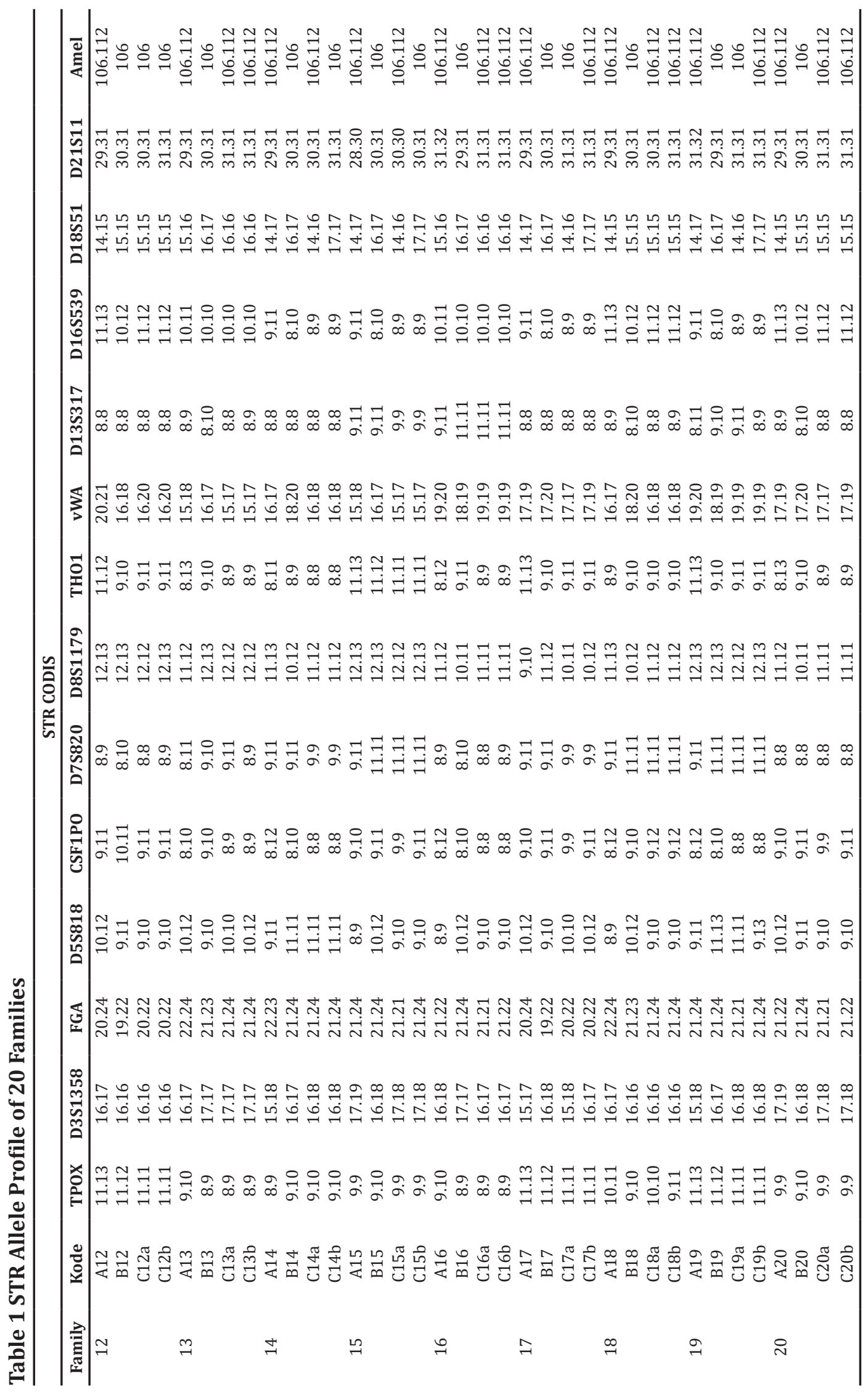


Table 2 Allele STR Frequency of Samples $(n=160)$

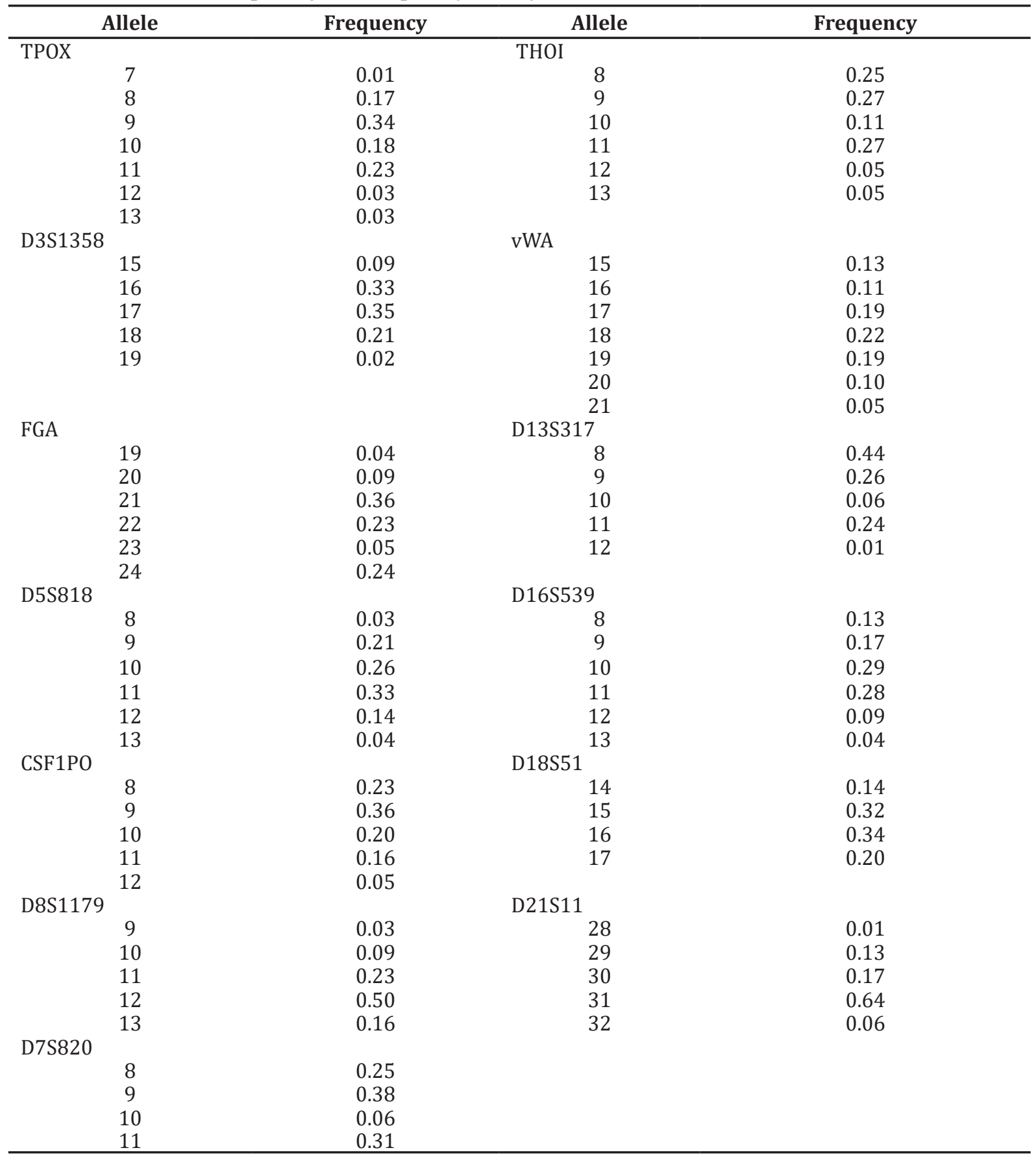

Amelogenin loci.

Allele sharing frequencies were based on kinship analysis between siblings in each STR CODIS (Figure 2). Allele sharing percentage on siblings using STR CODIS loci consisted of TPOX, D3S1358, FGA, D5S818, CSF1P0, D7S820, D8S1179, TH01, vWA, D13S317, D16S539, D18S51, D21S11. The amelogenin loci were interpreted with blue color represented 0 allele sharing, red color represented 1 allele sharing, and black color represented 2 allele sharing.

\section{Discussion}

DNA sample extraction results were measured for their level and purity, with a mean DNA sample level of $675 \pm 5.35 \mathrm{ng} / \mu \mathrm{L}$ and DNA purity ranged 
from 1.05-1.86. The PCR amplification through 13 STR-CODIS loci primers as well as PCR results in visualization through polyacrylamide agarose gel electrophorese [PAGE] with silver nitrate staining, including the PCR visualization results, were as follows: Individual genetic material is obtained from both parents by $50 \%$ each. Since a person's nuclear DNA is inherited from the father and mother, it is said that nuclear DNA [nDNA] is inherited in a Mendelian manner. Mendel's law 1 [Segregation of allelic genes] sets the rules of allele separation at the time of gamete formation, which occurs by meiosis, in which homologous pairs separate from each other and do not pair again or, in other words, there is a free separation of gene alleles from diploid to haploid. $6,7,8$

In genetics, alleles are alternative forms of genes at a locus in correlation to trait expression (phenotype). Alleles are formed due to nitrogen base sequence variations caused by mutations. In an individual, allele pairs determine the individual genotype. The term allele arises from the use of allelomorphs in Mendel's Principles of Heredity. ${ }^{4,8,9}$ Individuals who have the same allele at a locus are said to have homozygous genotypes, while those who have different alleles are said to be heterozygous. Because genotype is expressed as a phenotype, alleles might cause differences in appearance among individuals in a population. ${ }^{4,5}$

A paternity test is a DNA test to determine whether a man is the biological father of a child or not. Cases of family disputes, for example when the parents are doubted, are increasingly found in Indonesian society. ${ }^{3}$ Parents are the comparisons in a paternity test, where the obtained results are statistically near to $100 \%$ or around $99.99 \% .{ }^{10}$ Unavailability of child's parent information for comparison in the forensic DNA examination process is one of the problems that might occur in forensic DNA analysis. ${ }^{1}$ Unlike DNA testing that uses thparent's DNA as comparisons, individual identification using siblings' DNA has a lower accuracy rate, which is not approaching $100 \% .^{11}$

For the results of our study regarding STR CODIS loci alleles on paternity test in Human Genetic Study group ITD Universitas Airlangga, the highest percentage of locus alleles are as follows: TPOX allele 9 (34\%), D3S1358 allele17 (35\%), FGA allele 21 (36\%), D5S818 allele 11 (33\%), CSF1PO allele 9 (36\%), DS820 allele 9 (38\%), D8S1179 allele 12 (50\%), THOI allele 9 (27\%), vWA allele 18 (22\%), D13S317 allele 8 (44\%), D16S539 allele 10 (29\%), D18S51 allele 16 (34\%), and D21S11 allele 31(64\%) (Table 2).
The identification principle through DNA is based on the allele comparison process between alleles from the victims or perpetrators and alleles from the family line, especially parents, by following the Mendel's law. ${ }^{12,13,14}$ However, if parental or biological child lines are not available, a comparison is needed from the close family line as one of the methods that can be considered in identification through DNA, such as from siblings. The use of sibling as a comparison in identification methods is known as the kinship analysis. Kinship analysis in the identification process uses siblings as a comparison, as in the paternity test, albeit with a possibility of mismatch in the used DNA locus profile. ${ }^{7,11,14,15}$

In kinship analysis, allele sharing plays an important role. Allele sharing in determining siblings is very useful in establishing the relationship between siblings when both alleles are involved. Statistically, full siblings have a 2 -allele accuracy of $(0.25) 25 \%$. This value is the same as not having the same allele or 0 allele, while the accuracy of 1 allele reaches $50 \%{ }^{11}$

The result of this study is different from the theory presented by O'Connor where all CODIS STR loci examined showed that allele sharing is dominated by 2 -allele sharing. ${ }^{11}$ This might be due to the fact that the data used in this study were for paternity testing and were not only conducted in certain races or ethnicities but almost all races or ethnicities undergoing paternity testing at the Human Genetic ITD study group, Airlangga University, Indonesia. Markers are needed in personal identification of forensic DNA, especially in a paternity test, to eliminate the doubts in the mind of a forensic DNA expert when drawing conclusions. This can be done through mitochondrial DNA [mtDNA] and Y chromosome [Y-STRs] examinations as available alternatives. ${ }^{4}$

Allele sharing is a genetic variation inherited from both parents. All individuals are part of the population resulted from the mating between individuals and have the same gene pool. A gene pool is a collection of all genes/alleles in the population. ${ }^{7}$ Hardy-Weinberg Equilibrium Principle emphasizes that in a population that is in equilibrium, genes and genotype frequencies will remain from one generation to the next. This is found in large populations, marriages that take place randomly, and no attempt to regulate certain traits. ${ }^{8}$

The paternity test is based on the allele comparison process from both parents. According to Mendel law, if there is no available comparison from the parents, the closest family/kinship line 
will be compared, especially from the parental line. One of these kinship lines is from siblings. When assessing full sibling relationships, careful consideration must be taken from the highfrequency STR loci at 2-allele shares. The results of this study demonstrated that all CODIS STR loci have the highest percentage of 2-allele sharing. Therefore, it is recommended that paternity tests might be conducted through sibling or kinship pathways [kinship] if both parents are not present.

This study concludes that forensic identification using kinship analysis can be done using the STR-CODIS locus but there is some distinction in the percentage and qualification of using this locus. The main reason for forensic identification using kinship analysis is based on the Mendelian law, which stated that the parents' genes will be inherited by their descendants. Thus, sibling's DNA can be used as comparison for paternal testing when the parents' DNA is absent.

\section{References}

1. Fraige $\mathrm{K}$, Travensolo RF, Carrilho E. Analysis of seven human loci for paternity testing by microchip electrophoresis. Braz Arch Biol. Technol. 2013;56(2):213-21.

2. Yudianto A. Pemeriksaan identifikasi forensik molekuler. Surabaya: Global Persada Press; 2015.

3. Syukriani YF. DNA forensik. Jakarta: Sagung Seto; 2012.

4. Jaber MMT, Mohamed NS, Ahmed NS. Study genetic variation of 15 Autosomal short tandem repeat (STR) loci in Maysan Muslim individuals. Journal of Engineering Science and Technology Review. 2018;2(8):1148-60.

5. Butler JM. The future of forensic DNA analysis. Philos Trans R Soc Lond B Biol Sci. 2015;370(1674):20140252.
6. Elston RC, Satagopan JM, Sun S. Genetic terminology. Methods Mol Biol. 2012;850:19.

7. Mangoendidjojo W. Genetika populasi. Yogyakarta: Gadjah Mada University Press; 2014.

8. Negi DS, Shrivastava P, Das SP. Biochemical characterization of Molecular Markers for Human Genetic Identification in Paternity testing by DNA profiling. Asian Journal of Biomedical and Pharmaceutical Sciences. 2014;4(37):52-6.

9. Li JN, Luo HB, Song F, Hou YP. Genetic polymorphisms of 22 autosomal STR loci in Chinese Han population. Forensic Sci Int. 2015;5:e45-7.

10. Prastowo W, Lyrawati D, Andarini S, Mintaroem K. Allele frequencies of STR CODIS 13 of Madura Ethnic from Bangkalan and Probolinggo. Research Journal of Life Science. 2018;5(2):116-20.

11. O'Connor KL. Interpretation of DNA typing results for kinship analysis. Washington DC: National Institute of Standards and Technology USCIS Working Group on DNA Policy; 2011.

12. Hares DR. Selection and implementation of expanded CODIS core loci inthe United States. Forensic Sci Int Genet. 2015;17:33-4.

13. Maeda K, Murakami C, Irie W, Sasaki C, Oishi $\mathrm{M}$, Nakamaru N, et al. The case of 2 siblings that identified not only by DNA profiling. For Sci Int. 2015;5:e555-6.

14. Marano LA, Fridman C. DNA phenotyping: current application in forensic science. Res Rep in Forensic Med Sci. 2018;9:1-8.

15. Sosiawan A, Yudianto A, Furqoni AH, Nzilibili SM and Indah N. Full-Sibling Allelic frequency and sharing among Madurese: STR technique by 12 locus and the sex-typing amelogenin gene. Egypt J For Sci. 2019;9:38. 